Brazilian Journal of Political Economy, vol. 32, $n^{\circ} 4$ (129), pp. 700-702, October-December/2012

\title{
A graphic explanation on how a tax on exports neutralizes the Dutch disease without costs to exporters
}

\section{LUIZ CARLOS BRESSER-PEREIRA*}

The adequate way of neutralizing the Dutch disease is the imposition of a variable tax on the export of the commodity that originates the disease. If such tax is equivalent to the "size" of the Dutch disease, it will shifts to the right its supply curve of the commodity in relation to the exchange rate, giving the existing domestic supply and the international demand, the exchange rate will depreciate at the value of the tax, and the equilibrium exchange rate will move from the "current" to the "industrial" equilibrium.

Keywords: exchange rate; Dutch disease; tax on exports.

JEL Classification: F31; F4; O11.

In my original paper on the Dutch disease (Bresser-Pereira, 2007) I claimed that the adequate way to neutralize the Dutch disease is to establish a variable tax on the commodity or commodities that originate it. In a more recent paper I returned to the theme and stated that:

The neutralization of the Dutch disease is mainly effected through the imposition of a variable tax or levy on the commodity exports equal to the difference between the two rates in domestic currency [...] Once established an export tax, the supply curve of the commodity will shift upwards and to the left with regard to the exchange rate, that is, the producers will only be inclined to maintain production if the exchange rate depreciates in an amount corresponding to the tax. Therefore, if the tax is equal to the difference between the current equilibrium exchange

\footnotetext{
* Emeritus Professor of Getulio Vargas Foundation. E-mail: bresserpereira@gmail.com.
} 
rate and the industrial equilibrium exchange rate, the first one will shift towards the second and the Dutch disease will be neutralized [...] Even paying the tax, the commodity producers will continue to have the same profits; it is the country's population that "will pay" it, through the relative increase in the price of non-tradable goods resulting from the devaluation ${ }^{1}$, (Bresser-Pereira, 2012, pp. 354-355).

In this brief note I want just to present a graphic that demonstrates more precisely how a variable tax on exports of the commodity originating the Dutch disease will neutralize it without costs to exporters.

Figure: Neutralization of the Dutch disease by means of a tax on exports

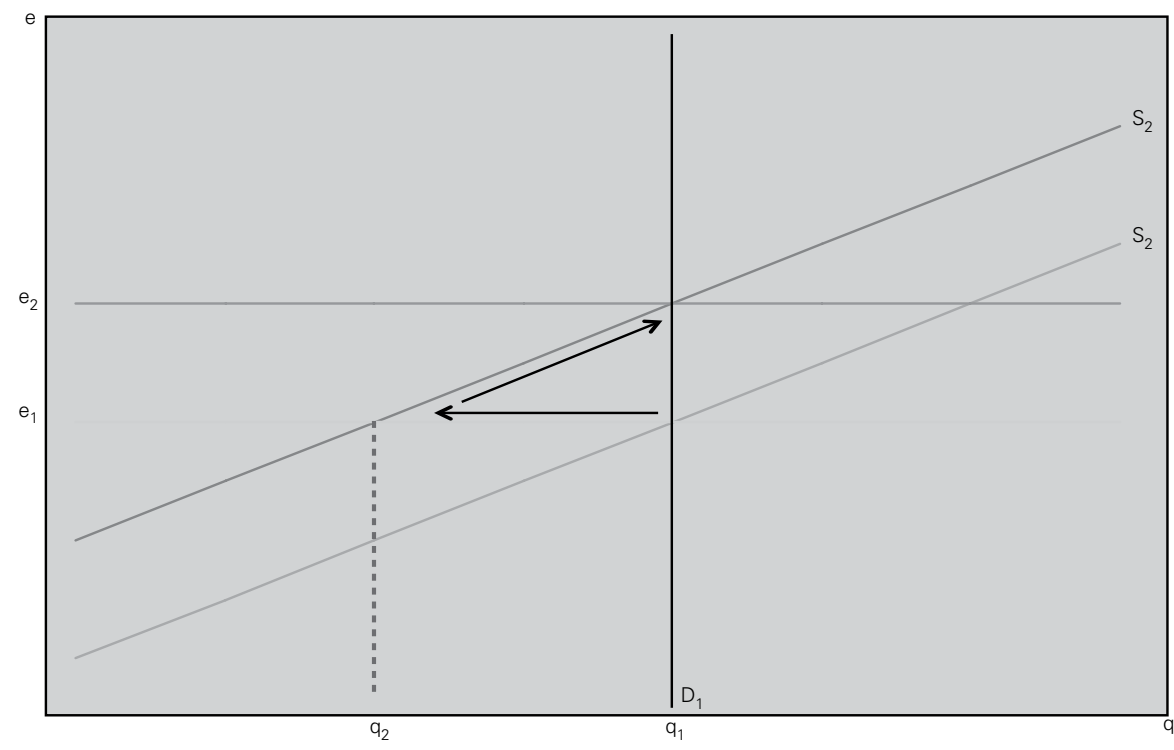

In this figure we have the exchange rate (not the price) in the vertical and quantities in the horizontal line. The difference between e1 (the current equilibrium exchange rate - the exchange rate that balances intertemporally the current account of the country) and e2 (the industrial equilibrium - the exchange rate that is required to business enterprises using technology in the world state of the art) is the size or the "seriousness" of the Dutch disease. The supply curve S1 and S2 are respectively the supply of the commodity benefiting from Ricardian rents and, for that reason, originating the Dutch disease before and after the export tax. The export tax is equal to the size of the Dutch disease (e1-e2). D1 is the demand curve in relation to the exchange rate; it is fully inelastic since the exchange rate of the

\footnotetext{
${ }^{1}$ Bresser-Pereira, Luiz Carlos, "Strucutralist macroeconomics and the new developmentalism", Brazilian Journal of Political Economy, 32 (3), July 2012, pp. 347-366.
} 
country does not affect it. The world demand and the international prices are given; if the country is big enough to affect the total supply of the commodity, that would complicate the figure, because it would be necessary backwards and a little later forward that demand curve, but it would not change the analysis. Given the demand and the exchange rate, the quantity exported is q1.

As elementary microeconomics teaches, the tax causes the shift of the supply curve. The quantity offered at this exchange rate falls to $\mathrm{q} 2$, because the less efficient producer will consider stopping production. But since the demand is inelastic in relation to the exchange rate, and, thus, constant, the exchange rate will depreciate from e1 to e2, so as reestablish the equilibrium between the existing supply and demand. And the depreciation of the exchange rate will be equal to the tax paid by the exporters, i.e., to the size of the Dutch disease. Assume, for instance, that the industrial equilibrium is $\mathrm{R} \$ 2.70$ per dollar and the current equilibrium, $\mathrm{R} \$ 2,20$ per dollar. If the effective exchange rate is in current equilibrium, because it is not being depreciated further by excessive capital inflows, a tax of $\mathrm{R} \$ 0.50$ per dollar will move the exchange rate to $\mathrm{R} \$ 2.70$ per dollar. The tax should be variable to be changed by the government as the international price of the commodity changes substantially.

Thus, what the producer pays in tax he receives back in depreciation. If we suppose that both changes are immediate, he will bear no cost. If we release such assumption - what is more realistic — there will be a "transition cost" for him, what explains why commodity exporters are so keen in opposing the tax. Labor will have to pay a similar transition cost, because their wages will fall for a while. The difference is that workers will be soon compensated by a substantial increase in rate of increase of the wage rate that will follow, while the commodity exporters will be just back to their original position. This suggests that the government will have more difficulty with them, and will probably offer some guarantees as, for instance, that (1) it will make an special effort in terms of increasing capital controls or buying more dollars to make the transition to the new equilibrium faster, and (2) that it will use of part of the tax as a guarantee fund for the price of the commodity - what will be attractive if the overappreciation is not to big (or the Dutch disease is not to serious), because, in this circumstance, the price of the commodity may fall enough to make the average producer unprofitable. In this case, besides the tax going to zero, the producer would receive compensation from the fund. 